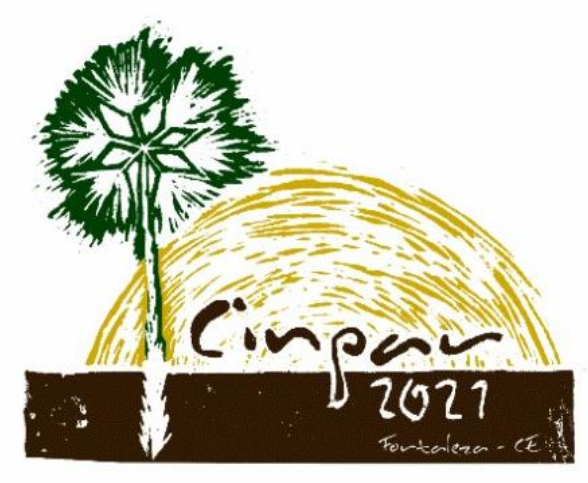

XVII Congresso Internacional sobre Patologia e Reabilitação das Construções

XVII Congreso Internacional sobre Patología y Rehabilitación de las Construcciones

XVII International Conference on Pathology and Constructions Rehabilitation

FORTALEZA (Brasil), 3 a 5 de junho de 2021

https://doi.org/10.4322/CINPAR.2021.054

\title{
Evaluation of degradation of about 20 -years-old precast concrete. A case study
}

\author{
Antonio BOSSIO ${ }^{1}$, Ersilia BIONDI ${ }^{2}$, Giuseppe FAELLA², Giorgio FRUNZIO², \\ Mariateresa GUADAGNUOLO ${ }^{2}$, Roberto SERPIERI ${ }^{2}$ \\ University of Naples Federico II, Naples, Italy, antonio.bossio@unina.it. \\ University of Campania Luigi Vanvitelli, Aversa, Italy, ersilia.biondi@unicampania.it, giuseppe.faella@unicampania.it, \\ giorgio.frunzio@unicampania.it, mariateresa.guadagnuolo@unicampania.it, roberto.serpieri@unicampania.it
}

\begin{abstract}
From the past century, precast and prestressed reinforced concrete is the most widely used building material throughout the world allowing covering longer spans and reducing structural weights. The societal and environmental relevance of unbiased assessment and prediction of concrete structure's serviceability is beyond question. A comprehensive scope of the mid- $20^{\text {th }}$ century scientific literature and of more recent research trends reveals controversial views between past and present on the expected engineering serviceability life of concrete structures because of chemical deterioration factors due to environmental exposure and, in particular, concerning rebar corrosion and possible related detrimental interaction with atmospheric carbon dioxide. A further parameter to take in due account for the serviceability assessment and prediction of $\mathrm{R} / \mathrm{C}$ structures is the variation of concrete strength over time.

This contribution reports the case study of an experimental campaign over three precast concrete elements of different typologies which, taken from undelivered lots never put into service after precasting, have remained fully exposed to weathering actions during a period ranging up to 20 years, in absence of loading. The campaign was designed to feature both partially destructive and non-destructive measurements. Starting from a careful visual inspection, it included core sampling, measurement of carbonation depth by phenolphthalein assays, compressive strength tests as well as corrosion potential mapping. A discussion is herein attempted on possible correlations factors emerging altogether from visual inspections, sampling, certified measurements, and from information on the environmental exposure conditions of the storage area.
\end{abstract}

Keywords: service life assessment, concrete degradation, carbonation, steel corrosion, prestressed concrete.

\section{Introduction}

Assessment and prediction of the service life of $(\mathrm{R} / \mathrm{C})$ structures have been recently raised as a major national concern in Italy by the collapses on August 14th, 2018 to the Polcevera bridge and on April 8th, 2020 to the Albiano Magra highway viaduct. Besides the loss of 43 lives, the Polcevera disaster alone has resulted in massive demolition and rebuilding of a viaduct segment more than one $\mathrm{km}$ long. This resulted in direct costs of more than 200 million euros, aside from indirect costs related to the prolonged interruption of the involved traffic routes and related to the consequently prolonged paralysis of the activities of the port of Genoa. The sudden character of these collapses, which have seemingly shown marked fragile kinematics, have led to arguing a possible role of concrete deterioration and steel corrosion and a related possible need for reconsidering the expected service life of $\mathrm{R} / \mathrm{C}$ elements of the first half and the middle of the last century. The urge for reliable diagnosis and prediction of $\mathrm{R} / \mathrm{C}$ structures serviceability concerning concrete deterioration and steel corrosion is also important for environmental reasons. The concrete industry 
contributes, indeed, up to approximately $8 \%$ of $\mathrm{CO}_{2}$ emissions from human activities on our planet (Olivier et al. 2015). In a perspective of limited planetary resources and strict $\mathrm{CO}_{2}$ reduction policies, granting reliable methodologies for assessing past and current serviceability expectations of R/C structures is a social and economic challenge for optimal management of the national $R / C$ building stock and $R / C$ infrastructures, and also represents a question posed to the research community in due consideration of environmental costs.

A wider perspective of the middle of the last century stated that well-designed and properly cast concrete with adequate chemical composition was not expected to present significant long-term structural problems and that corrosion protection could be granted. This opinion was supported by observations of ancient Roman constructions and by quantitative studies for long-term predictions of the service life of underground structures for nuclear waste repositories (Atkinson et al. 1985), Clifton and Knab 1985). Atkinson et al. (1985) estimate, in the worst projection, for a $1 \mathrm{~m}$ thick R/C section, an engineering lifetime (defined as halved loadbearing) longer than 180 years against an extremely severe exposition to sulphate attacks by underground waters, for an ordinary Portland concrete, and of 700 years for a "sulphate resisting cement". In the same study, the same service lifetime resistance against rebar corrosion ranges between 900 and 3000 years.

While the above-quoted projections of service life related to corrosion for underground structures may not be representative of exposure to atmospheric agents for above-ground structures, valuable review works can be retrieved in the literature of the past century, such as the popular manual by Luigi Santarella (1975), confirming achievable protection to corrosion. He reports that sufficient field observations and laboratory experiments had been accumulated at the time, showing evidence that, in absence of chemical attacks by acids or salts, the oxidation resistance is granted for steel bars embedded in concrete, provided embedment is properly designed and properly made. In support of this view, based on the investigation concerning the electrochemistry of corrosion and experimental campaigns of several years plus field observations, technical surveys dedicated to corrosion of steel in concrete published in the Journal of the American Concrete Institute and by the Texas Highway Department (Mozer et al. 1965, Houston et al. 1972), bring to the following remarkable conclusions:

- Mozer et al. (1965) remark that, although the electrochemical mechanisms underlying corrosion are extremely complex with different theories attempting a comprehensive explanation, often conflicting with one another, the ability of concrete to inhibit corrosion of steel is essentially determined by its water-tightness and its capability to provide a barrier to oxygen;

- Houston et al. (1972) show that complete corrosion protection is ensured even against the relatively severe exposure to daily spraying with a 3 percent salt solution over three years, provided that proper water/cement ratio, adequate concrete consistency, and sufficient concrete cover are adopted.

In favor of a perspective of prolonged serviceability life, it is worth recalling that aging of concrete should not only be thought of as a detrimental factor to resistance, since a strength gain is provided by the prosecution of hardening hydration reactions during the service life. The simplest estimate of an asymptotic $20 \%$ increment can be computed by extrapolating ordinary strength vs time tables during the first 28 days after casting time. This range is recently confirmed by destructive tests carried out by Ferraro and Fantilli (2020) on two bridges cast between the First and the Second World War: the Cardè bridge, which notably is the first $\mathrm{R} / \mathrm{C}$ bridge built over the Po river, and the bridge of Montaldo Roero.

A controversial picture is however gained when the conclusions of the sixties and seventies of the past century are compared with trends in the research of the subsequent decades. From the eighties onwards, much greater emphasis was placed by later scientific reports and technical documents, such as the Tuutti thesis (1982) and the FIB/CEB state of the art reports of 1982 and 1992 on concrete carbonation as the primary detrimental factor of the corrosion of embedded bars and the reduction of the service life of concrete structures (Basile et al., 2015; Biondi et al. 2019; Bossio et al. 2018). Many papers also investigate the loss of performance of R/C structures due to corrosion (Bossio et al., 2019; Imperatore et al., 2019). An even overturned perspective on corrosion is emphasized in a survey report of 2015 by Tang et al. (2015) on the durability of concrete structures, where it is stated that corrosion is "a headache problem in practical engineering".

Such a detrimental role of carbonation and corrosion conflicts with the past view of a relatively marginal concern towards carbonation as a steel corrosion factor. For instance, Mozer et al. (1965) stated that enough

Evaluation of degradation of about 20-years-old precast concrete. A case study. 
evidence had been accumulated at the time leading to view carbonation not likely to proceed beyond few millimeters in a properly made concrete. Besides, a concern towards carbonation conflicts with the common perspective shared in the field of unreinforced masonry according to which this phenomenon is the desirable hardening factor responsible for the conversion of calcium hydroxide to calcium carbonate in aerial mortars.

By comparing past research results and present research trends, a somehow controversial picture is gained on the techniques for corrosion measurement of embedded steel bars. Since the beginning of the eighties onwards, research has placed more emphasis on the possibility of employing, in total or partial replacement of sampling, indirect non-destructive measurements of corrosion rates by electrochemical techniques for on-site corrosion detection such as half-cell potential measurements and linear polarization measurements (Elsener et al. 2003, Ebell et al. 2018, Andrade 2020). On the other hand, laboratory studies investigating possible sources of discrepancy and error were reported by Indig and Groot (1969), showing that, even in a highly electronically controlled laboratory autoclave set-up with accelerated corrosion in stainless steel, limitations do exist in the employment of linear polarization techniques (when these are not corroborated by other measures or observations). Therein, the authors warn that these limitations could lead to a rejection of a material that could give instead satisfactory service, thus raising a question on the reliability of in-situ linear polarization tests, which, as a norm, are performed under many less-controlled conditions.

Besides theoretical-experimental research perspectives aiming at projections applicable to the largest possible classes of concrete structures, one should not overlook a due consideration of the individuality of a given structural element determined by the peculiar chemical composition of its concrete, by its structural typology and specific workmanship quality, and by its particular environmental exposure and service history.

In an attempt to gain an unbiased understanding of past and present knowledge on serviceability assessment of $\mathrm{R} / \mathrm{C}$ structures as well as of merging wide breadth and close-view research, a case study is herein reported of an experimental campaign carried out at the Department of Architecture and Industrial Design in Aversa over a group of precast concrete elements which, never being put into service after their precasting which took place between 2000 and 2006, have been exposed to weathering actions. These elements were stocked in an open storage area located next to the precast concrete prefabrication plant situated in Caiazzo in the north of the Campania Region in Italy. The elements object of study consist of precast R/C columns and prestressed $\mathrm{R} / \mathrm{C}$ omega and tee beams. The elements, while being previously scheduled for disposal, were kindly made available to the scientific investigation by the prefabrication company Sviluppo Silicalcite Sas.

The measurements carried out consisted of extraction of core samples, visual inspection of cored concrete surfaces in search of possible oxidation evidence, and phenolphthalein assays consecutively performed after extraction. These on-site activities were followed by compressive strength tests carried out in a certified laboratory. The campaign included corrosion rate measurements performed by the half-cell method.

Upon describing materials and methods, test results are reported. Finally, a discussion is attempted on reliability and predictive elements inter-subjectively emerging from this case study, filtered in the light of past and present knowledge gained on serviceability assessment and prediction of concrete structures.

\section{Case study}

\subsection{Materials and methods}

\subsection{1 - Precast element typologies and related available data}

The case study consists of the close-up inspection combined with partially destructive and non-destructive testing of three precast $\mathrm{R} / \mathrm{C}$ elements each belonging to three structural typologies: one squared section column of ordinary R/C (labeled " $C$ " and shown in Figure 1a), one prestressed omega beam (labeled "B1" and shown in Figure 1b), and one prestressed tee beam (shown in Figure 1c and labeled "B2").

The elements pertain to undelivered lots that (although not suffering from any lower quality check issue) have remained stocked in the open air during a period ranging between 14 and 20 years. Years of casting are 2000 (specimen C), 2006 (B1), and 2004 (B2). Nominal Rc attributed to each specimen is 45 MPa. 

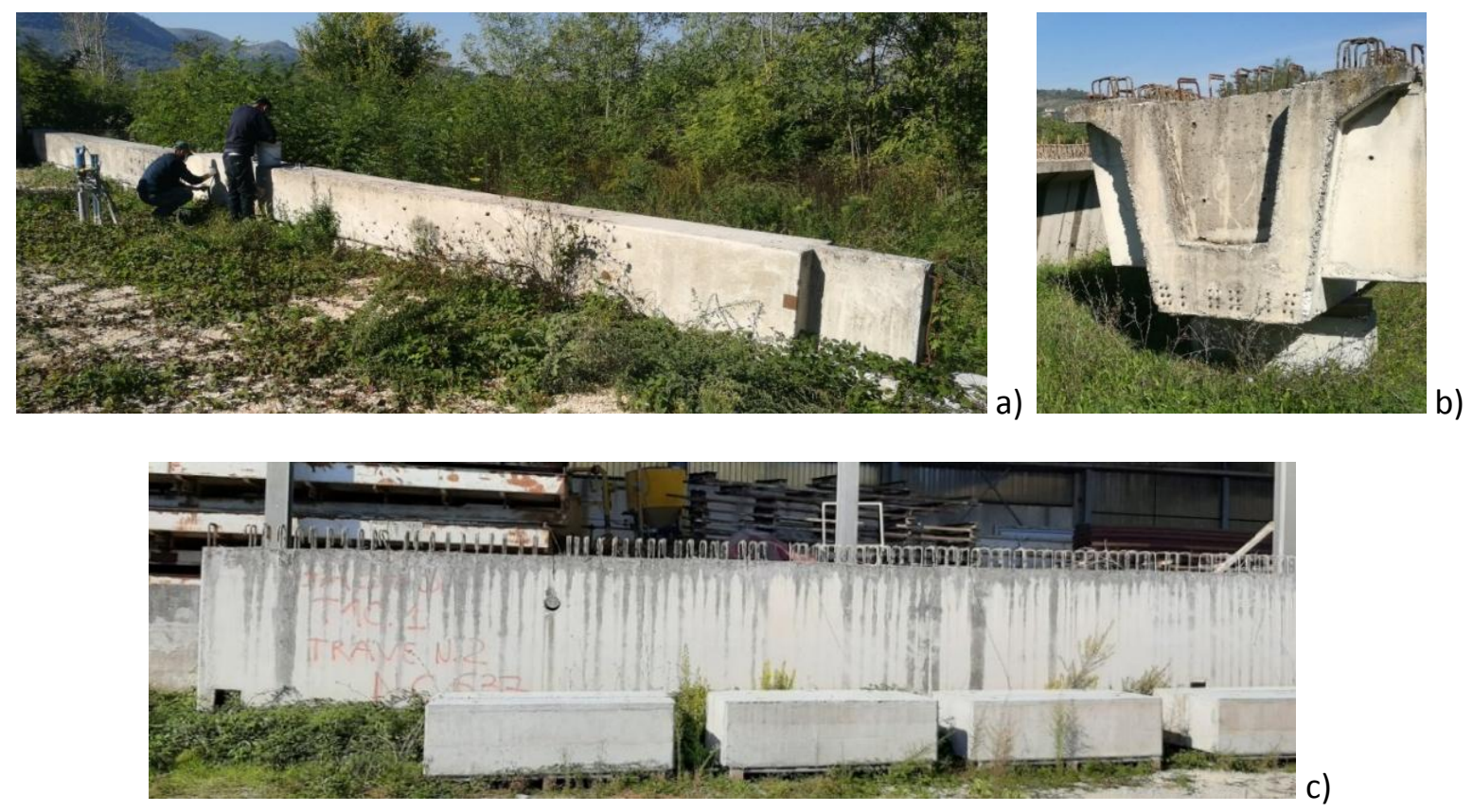

Figure 1 - a) Precast R/C squared column "C"; b) Prestressed R/C omega beam "B1"; c) Prestressed R/C Tee beam "B2"

\subsection{2 - Environmental conditions}

The analyzed structural elements were stored in the perimeter of the prefabrication plant situated next to the northern bank of Volturno river in front of Alifano mountain. Column " $\mathrm{C}$ " and beam "B1" are located on the NW side of the plant and beam "B2" on the SE side. Records of average environmental factors of the Caiazzo site were taken from the historical archives of the polyfunctional multi-risk centre, kindly provided by the Civil Defence of Caiazzo. Pluviometric and temperature records, as well as other weather parameters recorded since 2000 to date, are found to fall within averages of the Campania region. Average precipitation in depth is $850-900 \mathrm{~mm}$ concentrated in the winter period. The absence of significant pollution factors, or $\mathrm{CO}_{2}$ emissions of industrial or urban origin, is reported compared to regional averages. No information on possible specific sulphides or chlorides contamination sources from the environment was retrieved. Environmental conditions are often decisive for the persistence of mechanical performance.

\subsubsection{Testing methods}

The activities carried out consisted: 1) general visual inspection of the element and deterioration of concrete and steel surfaces exposed to atmosphere with an appraisal of clear concrete cover depths; 2) semidestructive tests consisting of extraction of concrete core samples, according to UNI EN 12504-1:2002; 3) visual inspection of concrete profile and possible oxidation evidence; 4) phenolphthalein assays according to UNI 9944/1992 by spraying $1 \%$ ethanol solution; 5) visual inspection of the surfaces of cores and cored space; 6) compressive strength tests carried out in a certified laboratory according to UNI EN 12390-1/2012 and UNI EN $12390-3 / 2019$; 7) corrosion rate mapping performed by half-cell potential method, using a $\mathrm{CU}_{\mathrm{CUSO}}$ counter electrode according to ASTM C876-15 and UNI EN 10174:2020.

\section{Test execution and Results}

\subsection{Core sampling}

Hollow steel tube diameters for concrete sampling were defined in consideration of aggregates size and structural element geometry. For column " $\mathrm{C}$ " and beam "B2" cylinders samples of diameter $10.4 \mathrm{~cm}$ were extracted while for beam "B1" the sample diameter was $7.0 \mathrm{~cm}$. Cored sample lengths were approximately $14 \mathrm{~cm}$ or longer. From each of the three structural elements of this study two samples were extracted (C1 and C2 for the column C, B1_1 e B1_2 for the beam B1, B2_1, and B2_2 for the beam B2). 
Core sampling was executed in compliance with UNI EN 12504-1/2002 technical standards (Fig. 2a). The employed core sampler device consists of an electrical engine actuating a rotating annular diamond drill bit tool backed up by a cylindrical hollow drill pipe, which is held in a horizontal position, and pressed against the vertical surface of the concrete element to be sampled (see Fig. 2b). Horizontal movement for penetration into concrete is allowed by a gear rack system. Drilling was carried out ensuring a constant degree of wetting of the rotating drill bit to reduce heating and for removal of comminuted concrete residual. After extraction, each sample was labeled by pencil marker and coring direction with respect to the concrete casting direction was recorded. Each specimen was photographed next to the relevant core hole.
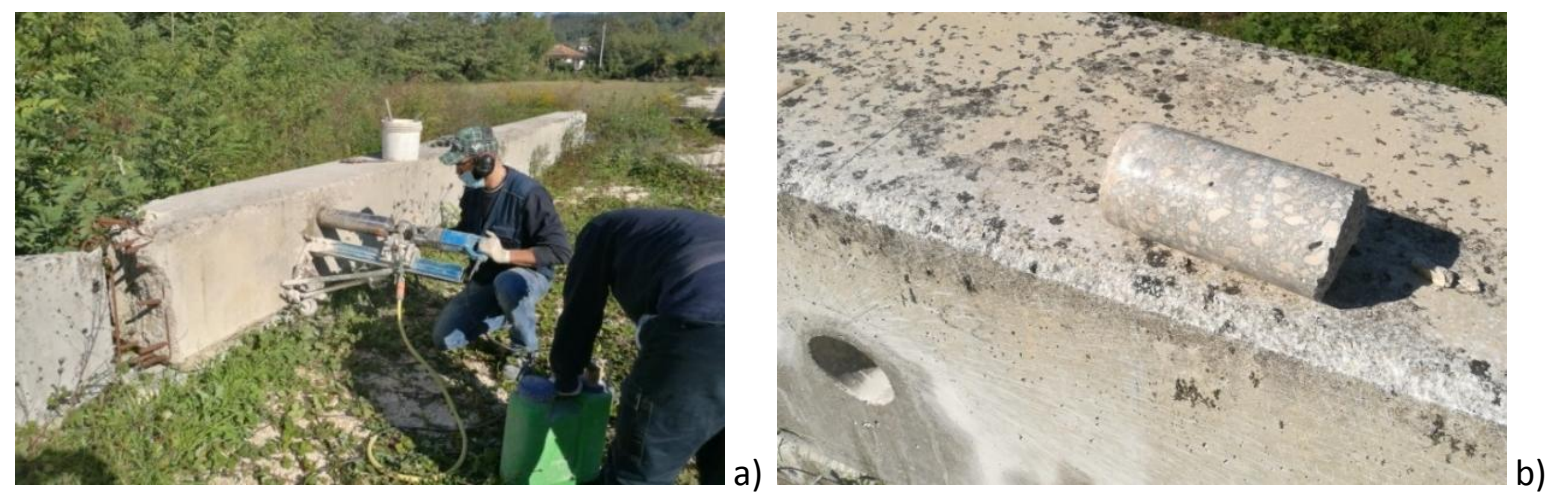

Figure 2 - a) coring execution for sample $\mathrm{C} 1$ on column $\mathrm{C}$; b) sample $\mathrm{C} 2$ on column $\mathrm{C}$

\subsection{Visual inspections}

Beams and columns appeared in a good state of conservation, aside from obvious visible brownish signs of oxidation overall unprotected steel surfaces directly exposed to atmospheric oxygen and rainwater (see, e.g., Fig.3a). Cracks revealing symptoms of concrete spalling and delamination were visible in circumscribed regions along the surfaces of the structural elements= For instance, clear evidence of delamination and spalling became visible after column $\mathrm{C}$ was struck by a hammer (Fig. $3 \mathrm{~b}$ ). Debris of cover delaminated upon hammer strike, Fig.3c, revealed the presence of an insufficient cover approximately $1 \mathrm{~cm}$ thick. Concrete surfaces resulting from core sampling showed well-sorted grain size distribution and adequate compaction. No visible corrosion was found in the bar segments embedded in the extracted samples.
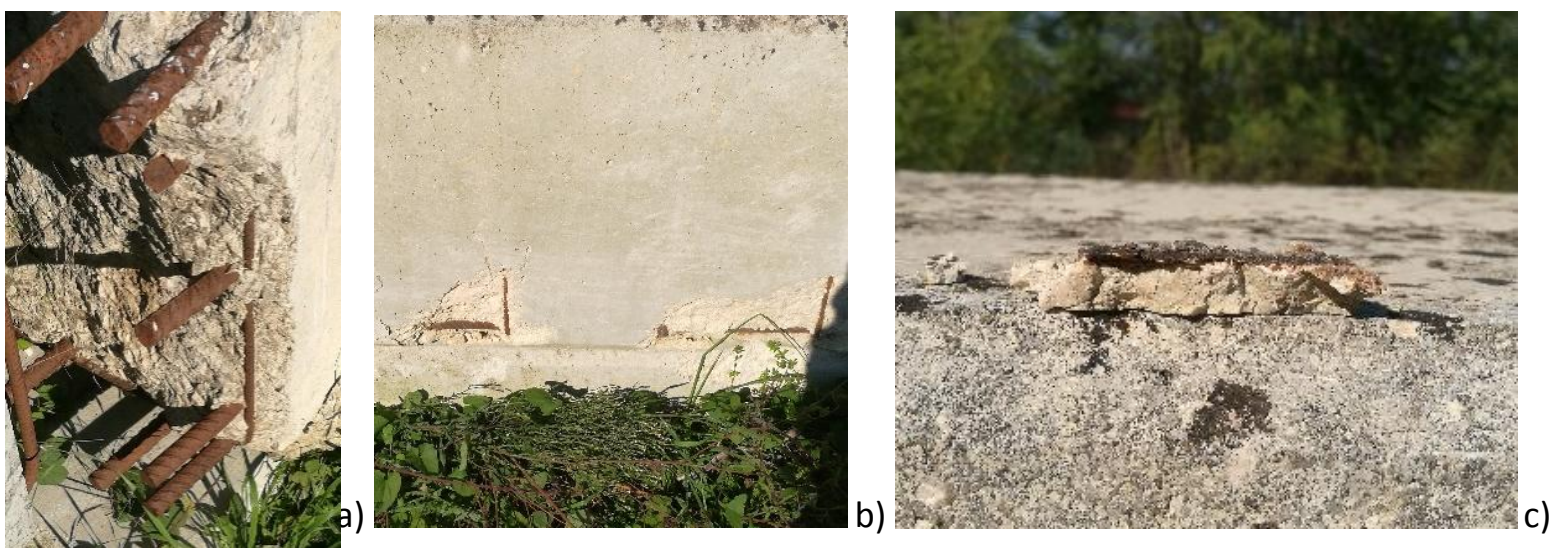

Figure 3- a) photograph of rusted exposed steel surfaces; b) evidence of delamination and spalling revealed after column $\mathrm{C}$ was struck by hammer; c) debris of detached cover delaminated upon hammer strike

\subsection{Compressive strength tests}

Compressive strength was measured according to the following five standard codes: British Standard EN 12504-1, 2009 (BS); Italian National Building Code, 2018 (NTC); American Concrete Institute 214.4R-03, 2003 (ACI); UNI EN 13791, 2007 (UNI EN); Concrete Society, 1987 (CS). To find accordance with the greatest number of recommendations in these standards relevant to compressive strength measurement from cored 
samples, cylindrical samples were cut and ground in smaller specimens of height to diameter ratio $H / D=1$. Geometrical parameters (diameter $\phi$, height $\mathrm{H}$ ) relevant to specimens for compressive strength testing are the following: $\phi=\mathrm{H}=104 \mathrm{~mm}$, for specimens $\mathrm{C} 1$ and $\mathrm{C} 2 ; \phi=\mathrm{H}=70 \mathrm{~mm}$, for specimens B1_1 and B2_2; $\phi=\mathrm{H}=104 \mathrm{~mm}$, for specimens B2_1 and B2_2. Table 1 reports the cubic strength values as processed according to the five considered standards. The table also reports the relevant Rc mean strength, computed by taking the average of these five values, as well as the reference value for Rc nominal strength which was retrieved from technical documentation of the prefabrication lot.

Table 1 - Concrete strength according to International standard codes (MPa)

\begin{tabular}{|c|c|c|c|c|c|c|c|c|c|}
\hline Specimen & $\mathbf{f}_{\text {core }}$ & BS & NTC & ACl & UNI EN & CS & $\begin{array}{c}\mathbf{R}_{\mathrm{c}} \text { mean } \\
\text { strength } \\
\mathbf{M P a}\end{array}$ & $\begin{array}{c}\mathbf{R}_{\mathrm{c}} \text { nominal } \\
\text { strength } \\
\mathbf{M P a}\end{array}$ & $\begin{array}{c}\text { Variation } \\
\%\end{array}$ \\
\hline C1 & 38.43 & 42.60 & 40.74 & 43.38 & 45.22 & 37.05 & 41.80 & 45 & -7.12 \\
\hline C2 & 45.50 & 50.43 & 48.23 & 51.53 & 53.53 & 43.85 & 49.51 & 45 & 10.03 \\
\hline B1_1 & 39.20 & 43.45 & 41.56 & 45.79 & 46.12 & 37.79 & 42.94 & 45 & -4.58 \\
\hline B1_2 & 46.52 & 51.56 & 49.31 & 54.52 & 54.72 & 44.83 & 50.99 & 45 & 13.31 \\
\hline B2_1 & 35.56 & 39.42 & 37.70 & 40.08 & 41.84 & 34.28 & 38.66 & 45 & -14.08 \\
\hline B2_2 & 29.87 & 33.11 & 31.66 & 33.58 & 35.14 & 28.79 & 32.46 & 45 & -27.87 \\
\hline
\end{tabular}

\subsection{Carbonation tests}

Figure 4 reports views of the core samples after spraying. Four out of six core samples showed a complete absence of neutralization below pH 9.2. Two samples (B1_1 and B1_2 extracted from beam B1) showed neutralization with carbonation depth ranging between $10 \mathrm{~mm}$ and $20 \mathrm{~mm}$. This quite singular condition for carbonation can be also explained by the relatively short life of the examined structural elements, ranging between 14 and 20 years, and by a possible difference in the concrete mix composition of beam B1.
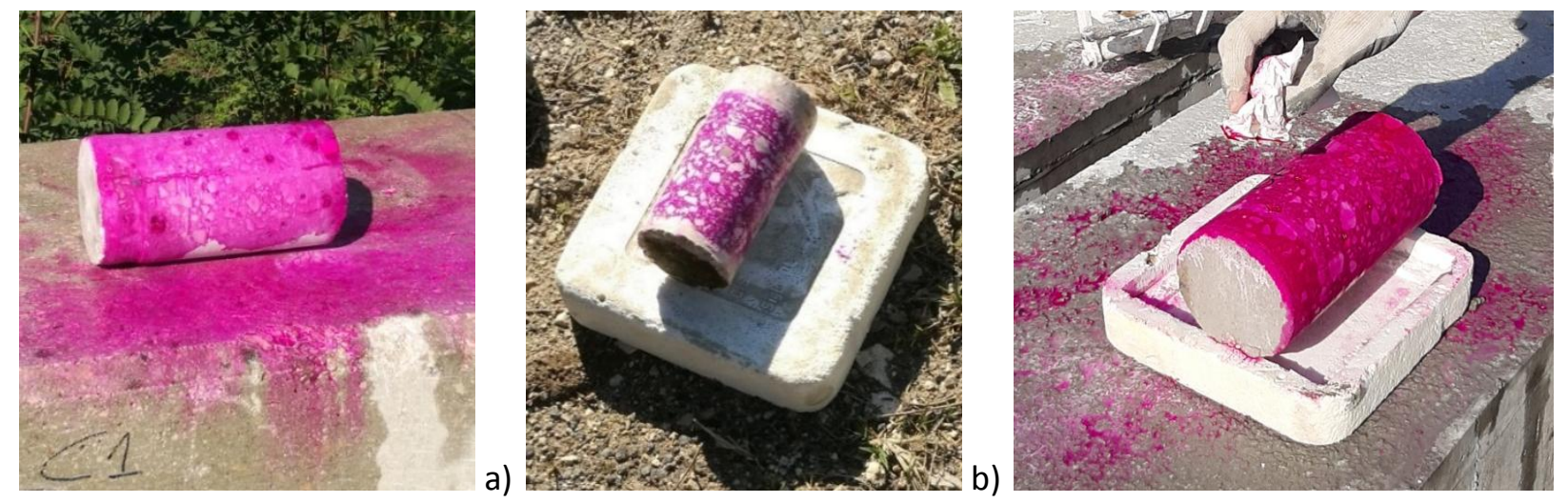

Figure 4 - Samples after phenolphthalein spraying: a) sample C1; b) sample B1_1; c) sample B2_1

\subsection{Corrosion Potential mapping}

Corrosion potential mapping is a non-destructive test consisting of the measurement of the potential difference between a reinforcing bar in concrete and a reference electrode placed on the concrete surface. Among different available reference electrode types, a $\mathrm{CU} / \mathrm{CUSO}_{4}$ electrode was used. Measurements were performed according to ASTM C876-15 and recommendations by Elsener et al. (2003) and Ebell et al. (2018).

Figure 5 indicates the values in $\mathrm{mV}$ of the registered corrosion potential, as measured over the three structural elements. Background colors from light green to red highlight potential values intervals in the range $(-200 \mathrm{mV},-350 \mathrm{mV}-\mathrm{Vs} \text {. CU/CUSO })_{4}$. Values higher than $-200 \mathrm{mV}$ are emphasized in light green while values lower than $-350 \mathrm{mV}$ in dark red. Concerning data interpretation, values higher than $-200 \mathrm{mV}$ were interpreted as an absence of corrosion, values in the range $(-200 \mathrm{mV},-350 \mathrm{mV})$ correspond to an increased 
probability of corrosion initiation; values lower than $-350 \mathrm{mV}$ are considered to be representative of corrosion initiation. It is remarked that some degree of arbitrariness exists on the definition of thresholds.

Altogether, the potential values in Fig. 5 were explained as follows. Variations of measured potential can be ascribed to variations of the concrete cover thickness. Such variability, as previously reported, was revealed by removing the concrete cover. It can be presumed that minor corrosion initiation processes may have occurred, considering the reduced life of the structural elements, the low aggressiveness of the environment, the high compressive resistance of concrete (leading to a presumable low degree of porosity), as well as considering the highly controlled casting procedure that is typically achieved in prefabrication.

\begin{tabular}{|l|l|l|l|l|l|l|l|l|l|l|l|l|l|l|}
\hline \multicolumn{4}{|c|}{ Column C } & \multicolumn{5}{|c|}{ Beam 1 } & \multicolumn{5}{c|}{ Beam 2 } \\
\hline-222 & -252 & -236 & -244 & -261 & -245 & -260 & -255 & -284 & -277 & -267 & -254 & -278 & -300 & -243 \\
\hline
\end{tabular}

Figure 5 - Corrosion Potential Vs $\mathrm{Cu} / \mathrm{CuSO}_{4}$ in $\mathrm{mV}$ measured over structural elements

\section{Conclusions}

The main conclusions of the case study are summarized. Visual inspections confirm that only steel surfaces directly exposed to the atmosphere, or with insufficient or cracked cover, exhibit corrosion. Cored samples showed well-sorted grain size distribution and adequate concrete compaction. No perceivable corrosion was found in the sampled bar segments. Phenolphthalein assays revealed that, in 2 out of 6 samples, pH has dropped below 9.2. Such a contrasting picture for neutralization may be ascribed to the relatively short life of the examined elements, between 14 and 20 years, and to a possible difference in the concrete chemical mix composition of one beam (beam B1). While concrete strength turned out to be in one case lower than nominal values presumable from the technical documentation retrieved from the archives of the plant, a conclusion in this respect is herein reserved as the authors believe that a wider investigation is deserved with a broader account of the testing standards and statistical and technical parameters. Half-cell measurement led to estimating the absence of interior zones where the corrosion process may have been initiated. The big picture gained is that the measured high compressive strength of concrete is indicative of its low porosity, of good concrete compaction as well as of the adoption of a proper water/cement ratio. These parameters are indicative of adequate design and prefabrication of the concrete mix.

Altogether, the results that emerged from the present case study confirm the past knowledge that in a not exceedingly aggressive environment, adequate design and prefabrication of concrete cover and concrete mixture lead to structures able to attend their design service life. These conclusions must be validated through destructive loading testing of full-scale elements performed on the same beams and columns analyzed in this paper, since the prefabrication company has already expressed its willingness to allow the execution of these tests.

\section{Acknowledgments}

The contribution of the Ministry of Education, University, and Research is gratefully acknowledged.

Sviluppo Silicalcite Sas is gratefully acknowledged for making available the precast structural elements. Investigations were performed with equipment kindly provided by Tecnolab S.r.l. Testing support provided by Tecnolab S.r.l. is also gratefully acknowledged.

\section{References}

American Concr. Instit. 214.4R-03. (2003). Guide for Obtaining Cores and Interpreting Compr. Strength Results.

Andrade, C. (2020). Electrochemical methods for on-site corrosion detection. FIB Int. Fed. for Struct. Concr. ASTM, C 876-15 (2015). Standard Test Method for Corrosion Potentials of Uncoated Reinf. Steel in Concr. 
Atkinson, A., Goult, D. J., \& Hearne, J. A. (1985). An assessment of the long-term durability of concrete in radioactive waste repositories. MRS Online Proceedings Library (OPL), 50.

Basile, A., Frunzio, G., Mattiello, G. (2015). Diagnosis of the critical state of concrete. XIII International Forum Le vie dei Mercanti - Heritage and Technology, Scuola Pitagora Editore, Napoli, 1783-1791.

Biondi, E., Frunzio, G. (2019). Analysis of degradations for the conservation of reinforced concrete. World heritage and Legacy, ATTI XVII Forum Gangemi Editore, Roma, pp. 943-952.

Bossio, A., Imperatore, S., Kioumarsi, M. (2019). Ultimate flexural capacity of reinforced concrete elements damaged by corrosion, Buildings, 9(7), 160.

Bossio, A., Lignola, G.P., Prota, A. (2018). An overview of assessment and retrofit of corroded reinforced concrete structures, Procedia Structural Integrity, 11, pp. 394-401.

British Standard EN 12504-1:2009. Testing concrete in structures. Cored specimens.

CEB (1992). Durable Concrete Structures. Bulletin d'information 183.

Clifton, J.R., Knab L.I. (1989). Service life of concrete. No. NUREG/CR--5466. Nuclear Regulatory Commission.

Comite Euro-International du Beton. (1982). Durability of concrete structures. CEB, Paris, Bulletin 148.

Concrete Society (1987). Concrete core Testing for Strength, Tech.Rep. N 11. The Concr. Society, London, 44.

Ebell, G., Burkert, A.,Mietz, J. (2018). Detection of Reinforcement Corrosion in Reinforced Concrete Structures by Potential Mapping: Theory and Practice, International Journal of Corrosion.

Elsener, B., Andrade, C., Gulikers, J., Polder, R., Raupach, M. (2003). RILEM TC 154 EMC: Half cell potential measurements - Potential mapping on reinforced concrete structures, Materi. \& Struct. 36, pp. 461-471.

Ferraro, E., Fantilli, A. (2020) La resistenza dei calcestruzzi confezionati nella prima metà del ' 900. https://www.ingenio-web.it/24328-la-resistenza-dei-calcestruzzi-confezionati-nella-prima-meta-del-900.

Imperatore, S., Rinaldi, Z., Spagnuolo, S., (2019). Experimental investigations on the effects of the steel rebar corrosion at structural level, Structural Concrete, 20(6), pp. 2230-2241.

Indig, M. E., Groot, C. (1969). Some limitations of the linear polarization techniques in evaluating corrosion behavior. Corrosion, 25(11), 455-461.

Houston, J.T., Atimtay, E., Ferguson, P.M. (1972) Corrosion of reinforcing steel embedded in structural concrete. Research Report No. 112-1F. Res. Proj.Number 3-5-68-112. Texas Highw. Dept.

Mozer, J. D., Bianchini, A. C., Kesler, C. E. (1964). Corrosion of Reinforcing Bars in Concrete. Journal of the American Concrete Institute, August, 1965.

NTC 2018, Aggiornamento delle Norme Tecniche per le costruzioni. G.U. n. 42 del 20.02.2018. In Italian.

Olivier, J.G.J. et al. (2015). Trends in Global CO2 Emission: 2015 Report, The Hague.

Santarella, L. (1975). Il cemento armato. Volume I. La tecnica e la statica. $19^{\circ}$ edizione. Hoepli.

Tang, S.W., Yao, Y., Andrade, C., Li, Z.J. (2015). Cement and Concrete Research 78, 143-154. Elsevier.

Tuutti, K. (1982). Corrosion of steel in concrete. Cement-och betonginst.

UNI 10174:2020 Istruzioni per l'ispezione delle strutture di calcestruzzo armato esposte ad ambienti aggressivi mediante mappatura di potenziale. In Italian.

UNI 9944/1992 Corrosione e protezione dell'armatura del calcestruzzo. Determinazione della profondità di carbonatazione e del profilo di penetrazione degli ioni cloruro nel calcestruzzo. In Italian.

UNI EN 12390-1/2012 Testing hardened concrete - Part 1: Shape, dimensions and other requirements for specimens and moulds.

UNI EN 12390-3/2019 Testing hardened concrete - Part 3: Compressive strength of test specimens.

UNI EN 12504-1/2002 Prove sul CLS nelle strutture - Carote, Prelievo, esame e prova di compressione. In Italian.

UNI EN 13791:2007. Assessment of in-situ compr. strength in structures and precast concrete components. 